\title{
PENTINGNYA PENDEKATAN KETERAMPILAN PROSES PADA PEMBELAJARAN IPA DI MADRASAH
}

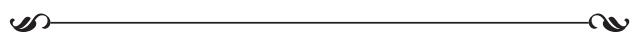

Laely Mahmudah

MTs Ma'arif NU 1 Patikraja, Banyumas, Jawa Tengah

or ca

\begin{abstract}
THE IMPORTANCE OF PROCESS SKILL APPROACH ON SCIENCE LEARNING IN MADRASA. Process skills approach is essential to be applied to science learning in Madrasa. Excellent process skills approach in the learning process, such as students directly involved with the real object so as to facilitate students understanding of the subject matter, the students find their own concepts studies, to train students to think more critically, to train students to ask and be more active in learning, encourage students to discover new concepts, provide an opportunity for students to learn to use the scientific method. Teachers in learning science apply process skills approach should make a good planning and making worksheet for learning more targeted, effective, and positive influence on the learning outcomes of students.
\end{abstract}

Key words: approach, Science learning, madrasa

\section{A. Pendahuluan}

Pembelajaran IPA di madrasah merupakan proses interaksi antara peserta didik dengan guru dan sumber belajar dalam membelajarkan pengetahuan-pengetahuan alam dan gejala-gejala alam. Berdasarkan karakteristiknya, IPA berhubungan dengan cara mencari tahu tentang alam secara sistematis, sehingga IPA bukan hanya penguasaan kumpulan pengetahuan yang berupa fakta-fakta, konsep-konsep, atau prinsip-prinsip saja tetapi juga merupakan suatu proses penemuan. Pemahaman tentang karakteristik IPA ini berdampak pada proses belajar IPA di madrasah. IPA di madrasah diharapkan dapat menjadi wahana bagi peserta didik untuk mempelajari diri sendiri dan alam sekitar, serta prospek pengembangan lebih lanjut dalam menerapkannya di dalam kehidupan sehari-hari.

IPA pada hakikatnya meliputi empat unsur utama, yaitu sikap, 
proses, produk, dan aplikasi. Keempat unsur itu merupakan ciri IPA yang utuh yang sebenarnya tidak dapat dipisahkan satu sama lain. Dalam proses pembelajaran IPA, keempat unsur itu diharapkan dapat muncul, sehingga peserta didik dapat mengalami proses pembelajaran secara utuh, memahami fenomena alam melalui kegiatan pemecahan masalah, metode ilmiah dan meniru cara ilmuwan bekerja dalam menemukan fakta baru (Kemendikbud, 2013: 212).

Keberhasilan belajar IPA yang dicapai peserta didik dapat diukur melalui penilaian hasil belajar. Keberhasilan dalam proses pembelajaran IPA dipengaruhi beberapa faktor antara lain persiapan perangkat pembelajaran, perancangan kegiatan pembelajaran dan persiapan materi yang akan dibelajarkan kepada peserta didik, lingkungan yang kondusif serta sarana dan prasarana yang baik. Salah satu faktor yang menentukan keberhasilan dalam pembelajaran adalah pemilihan pendekatan pembelajaran. Namun pada kenyataannya dalam pembelajaran yang sering terjadi guru hanya mentransfer begitu saja materi yang diuraikan dalam buku teks pada peserta didik. Materi pembelajaran disampaikan dengan cara atau metode ceramah, tanya jawab, dan tugas individu. Metode tersebut adalah cara yang paling mudah bagi guru bila dibandingkan dengan membelajarkan peserta didik melalui pendekatan atau model pembelajaran yang inovatif.

Kondisi riil madrasah menurut Khaeruddin et al. (2007: 12), kebanyakan para guru masih melaksanakan pembelajaran pola lama one man show, belum menjadikan peserta didik sebagai subyek dalam pembelajaran. Begitu pula dalam perencanaan pembelajaran seperti kesiapan silabus, rencana pengajaran harian dan alat evaluasi yang banyak tidak disiapkan dengan baik oleh guru. Ditambah lagi minimnya sumber belajar dan media pembelajaran serta alat peraga terutama laboratorium. Ini menyebabkan terjadinya pembelajaran yang monoton, membosankan, dan melelahkan. Kondisi seperti ini berdampak pada kurang optimalnya hasil belajar yang diperoleh peserta didik yakni belum mampu mencapai nilai pada mata pelajaran IPA sesuai standar kelulusan minimal (KKM).

Persoalannya bukan hanya karena kemampuan peserta didik yang rendah, namun perlu dikaji hal yang paling mendasar mempengaruhi rendahnya hasil belajar IPA termasuk pemilihan dan penggunaan pendekatan pembelajaran. Dalam pembelajaran guru seyogyanya membimbing peserta didik untuk menemukan sendiri konsep-konsep melalui kreativitas sendiri, 


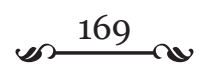

mengkonstruksi pengetahuan ke dalam pikirannya dengan menekankan proses daripada hasilnya. Agar pelaksanaan pembelajaran dapat menarik perhatian peserta didik perlu diterapkan berbagai macam pendekatan dalam pembelajaran sehingga mampu mengembangkan potensi dan menyenangkan bagi peserta didik.

Guru harus menguasai prinsip-prinsip pembelajaran, pemilihan, dan penggunaan media pembelajaran, pemilihan dan penggunaan metode pembelajaran, keterampilan menilai hasil belajar peserta didik, serta memilih dan menggunakan strategi atau pendekatan pembelajaran (Mulyasa, 2014: 100). Salah satu pendekatan pembelajaran yang penting untuk diterapkan adalah pendekatan keterampilan proses.

Ada empat alasan yang melandasi perlunya diterapkan pendekatan keterampilan proses menurut Semiawan, dkk. (1989: 14). Alasan pertama karena terdesak waktu untuk mengejar pencapaian kurikulum, maka guru akan memilih jalan yang termudah, yakni menginformasikan fakta dan konsep melalui metode ceramah. Akibatnya, para peserta didik memiliki banyak pengetahuan tetapi tidak dilatih untuk menemukan pengetahuan, tidak dilatih untuk menemukan konsep, tidak dilatih untuk mengembangkan ilmu pengetahuan.

Alasan kedua, para ahli psikologi umumnya sependapat bahwa peserta didik mudah memahami konsep-konsep yang rumit dan abstrak jika disertai contoh-contoh kongkret, contoh-contoh yang wajar sesuai dengan situasi dan kondisi yang dihadapi, dengan mempraktekkan sendiri upaya penemuan konsep melalui perlakuan terhadap kenyataan fisik, melalui penanganan benda-benda yang benar-benar nyata. Pada prinsipnya, peserta didik mempunyai motivasi dari dalam untuk belajar karena didorong oleh rasa ingin tahu. Tugas guru bukanlah memberikan pengetahuan, melainkan menyiapkan situasi yang menggiring peserta didik untuk bertanya, mengamati, mengadakan eksperimen, serta menemukan fakta dan konsep sendiri. Kalau peranan guru sangat dominan maka peserta didik akan sedikit sekali belajar, tidak berminat, dan peserta didik kehilangan motor penggerak tindakan atau motivasi.

Alasan ketiga, penemuan ilmu pengetahuan tidak bersifat mutlak benar seratus persen, penemuannya bersifat relatif. Apabila guru hendak menanamkan sikap ilmiah kepada peserta didik, maka peserta didik perlu dilatih untuk selalu bertanya, berpikir kritis, dan mengusahakan 


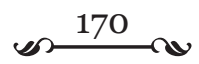

kemungkinan jawaban terhadap satu masalah. Peserta didik perlu dibina berpikir dan bertindak secara kreatif, yang terpenting bukanlah memberikan "ikan" kepada peserta didik untuk dimakan sebanyak-banyaknya, melainkan bagaimana memberikan "kail" kepada peserta didik untuk dapat memancing sendiri.

Alasan keempat, dalam proses pembelajaran seyogyanya pengembangan konsep tidak dilepaskan dari pengembangan sikap dan nilai dalam diri peserta didik. Jika yang ditekankan pengembangan konsep tanpa memadukannya dengan pengembangan sikap dan nilai, akibatnya adalah intelektualisme yang "gersang" tanpa humanisme. Tujuan kita adalah menghasilkan insan pemikir sekaligus insan manusiawi yang menyatu dalam pribadi yang selaras, serasi, dan seimbang. Dengan perkataan lain, peserta didik memiliki intelektual yang tinggi dan karakter yang kuat, sehingga dapat sukses dalam kehidupan.

\section{B. Pembahasan}

\section{Pendekatan Keterampilan Proses}

Devi (2010: 25) menyatakan bahwa pendekatan pembelajaran adalah proses penyajian isi pembelajaran kepada peserta didik untuk mencapai kompetensi tertentu dengan suatu atau beberapa metode pilihan. Pendekatan keterampilan proses adalah perlakuan yang diterapkan dalam pembelajaran yang menekankan pada pembentukan keterampilan memperoleh pengetahuan kemudian mengkomunikasikan perolehannya. Keterampilan memperoleh pengetahuan dapat dengan menggunakan kemampuan olah pikir (psikis) atau kemampuan olah perbuatan (fisik).

Hal senada disampaikan oleh Hosnan (2014: 370), pendekatan keterampilan proses adalah pendekatan dalam proses belajar mengajar yang menekankan pada keterampilan memperoleh pengetahuan dan mengomunikasikan perolehannya itu. Keterampilan proses berarti pula sebagai perlakuan yang diterapkan dalam proses pembelajaran dengan mengunakan daya pikir dan kreasi secara efektif dan efisien guna mencapai tujuan. Tujuan keterampilan proses adalah mengembangkan kreativitas peserta didik dalam belajar sehingga peserta didik secara aktif dapat mengembangkan dan menerapkan kemampuannya. Peserta didik belajar tidak hanya untuk mencapai hasil, melainkan juga belajar bagaimana belajar. 


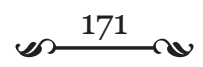

Keterampilan proses menurut Rustaman (2003: 23) adalah keterampilan yang melibatkan keterampilan-keterampilan kognitif atau intelektual, manual, dan sosial. Peserta didik menggunakan pikirannya/keterampilan kognitif dalam melakukan keterampilan proses. Keterampilan manual jelas terlihat pada saat menggunakan alat dan bahan, pengukuran, penyusunan, atau perakitan alat. Keterampilan sosial terlihat ketika terjadi interaksi peserta didik, misalnya mendiskusikan hasil pengamatan.

American Association for the Advancement of Science mengklasifikasikan keterampilan proses menjadi keterampilan proses dasar dan terpadu (Kemendikbud, 2013: 215). Klasifikasi keterampilan proses tersebut tertera pada tabel 1.

Tabel 1. Keterampilan Proses Dasar dan Terpadu

\begin{tabular}{|l|l|}
\hline Keterampilan Proses Dasar & Keterampilan Proses Terpadu \\
\hline Pengamatan & Pengontrolan Variabel \\
\hline Pengukuran & Interpretasi data \\
\hline Menyimpulkan & Perumusan hipotesa \\
\hline Meramalkan & $\begin{array}{l}\text { Pendefinisian variabel secara } \\
\text { operasional }\end{array}$ \\
\hline Menggolongkan & Merancang eksperimen \\
\hline Mengkomunikasikan &
\end{tabular}

Chiappetta \& Koballa (2010: 132), membagi keterampilan proses sains (science process skill) menjadi dua, yaitu keterampilan proses sains dasar dan terintegrasi. Keterampilan proses sains dasar mencakup mengobservasi/ mengamati, mengklasifikasikan, hubungan ruang/waktu, menggunakan bilangan,melakukan pengukuran, menginferensi, memprediksi. Keterampilan proses sains terintegrasi mencakup merumuskan definisi operasional, memformulasikan model, mengontrol variabel, menginterpretasi data, merumuskan hipotesis, melakukan eksperimen. Pada tabel 2 disajikan jenisjenis indikator keterampilan proses beserta sub indikatornya.

Tabel 2. Jenis-jenis indikator Keterampilan Proses beserta Sub Indikatornya 


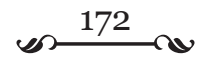

\begin{tabular}{|c|c|c|}
\hline No & Indikator & Sub Indikator Keterampilan Proses Sains \\
\hline 1 & Mengamati & $\begin{array}{l}\text { - Menggunakan sebanyak mungkin alat indera } \\
\text { - Mengumpulkan/menggunakan fakta yang } \\
\text { relevan }\end{array}$ \\
\hline 2 & Klasifikasi & $\begin{array}{l}\text { - Mencatat setiap pengamatan secara terpisah } \\
\text { - Mencari perbedaan, persamaan; } \\
\text { mengontraskan ciri-ciri; membandingkan } \\
\text { - Mencari dasar pengelompokan atau } \\
\text { penggolongan }\end{array}$ \\
\hline 3 & Menafsirkan & $\begin{array}{l}\text { - Menghubungkan hasil-hasil pengamatan } \\
\text { - Menemukan pola dalam suatu seri pengamatan; } \\
\text { menyimpulkan }\end{array}$ \\
\hline 4 & Meramalkan & $\begin{array}{l}\text { - } \text { Menggunakan pola-pola hasil pengamatan } \\
\text { - Mengungkapkan apa yang mungkin terjadi } \\
\text { pada keadaan sebelum diamati }\end{array}$ \\
\hline 5 & $\begin{array}{l}\text { Mengajukan } \\
\text { pertanyaan }\end{array}$ & $\begin{array}{l}\text { - Bertanya apa, mengapa, dan bagaimana } \\
\text { - Bertanya untuk meminta penjelasan; } \\
\text { mengajukan pertanyaan yang berlatar belakang } \\
\text { hipotesis }\end{array}$ \\
\hline 6 & $\begin{array}{l}\text { Merumuskan } \\
\text { hipotesis }\end{array}$ & $\begin{array}{l}\text { - Mengetahui bahwa ada lebih dari satu } \\
\text { kemungkinan penjelasan suatu kejadian } \\
\text { - Menyadari bahwa suatu penjelasan perlu diuji } \\
\text { kebenarannya dengan memperoleh bukti } \\
\text { lebih banyak atau melakukan cara pemecahan } \\
\text { masalah }\end{array}$ \\
\hline 7 & $\begin{array}{l}\text { Merencanakan } \\
\text { percobaan }\end{array}$ & $\begin{array}{l}\text { - Menentukan alat/bahan/sumber yang akan } \\
\text { digunakan } \\
\text { - Menentukan variabel/faktor penentu; } \\
\text { menentukan apa yang akan diukur, diamati, } \\
\text { dicatat; menentukan apa yang akan } \\
\text { dilaksanakan berupa langkah kerja }\end{array}$ \\
\hline
\end{tabular}




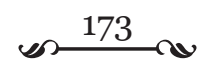

\begin{tabular}{|c|c|c|}
\hline No & Indikator & Sub Indikator Keterampilan Proses Sains \\
\hline 8 & $\begin{array}{l}\text { Menggunakan } \\
\text { alat/bahan }\end{array}$ & $\begin{array}{l}\text { - } \text { Memakai alat/bahan } \\
\text { - } \text { Mengetahui alasan mengapa menggunakan } \\
\text { alat/bahan; mengetahui bagaimana } \\
\text { menggunakan alat/bahan }\end{array}$ \\
\hline 9 & $\begin{array}{l}\text { Menerapkan } \\
\text { konsep }\end{array}$ & $\begin{array}{l}\text { - Menggunakan konsep yang telah dipelajari } \\
\text { dalam situasi baru } \\
\text { - Menggunakan konsep pada pengalaman baru } \\
\text { untuk menjelaskan apa yang sedang terjadi }\end{array}$ \\
\hline 10 & Berkomunikasi & $\begin{array}{l}\text { - Mengubah bentuk penyajian } \\
\text { - Menggambarkan data empiris hasil percobaan } \\
\text { atau penelitian; membaca grafik atau tabel } \\
\text { atau diagram; mendiskusikan hasil kegiatan } \\
\text { mengenai suatu masalah atau suatu peristiwa }\end{array}$ \\
\hline
\end{tabular}

Sumber: Kemendikbud (2013: 215)

\section{Beberapa Jenis Keterampilan Proses yang Dapat Dilatihkan Pada Peserta Didik di Madrasah}

Agar lebih memahami bagaimana menerapkan pendekatan keterampilan proses pada pembelajaran IPA, berikut ini uraian beberapa jenis keterampilan proses yang dapat dilatihkan pada peserta didik di madrasah.

a. Observasi atau pengamatan

Mengamati merupakan kegiatan mengidentifikasi ciri-ciri objek tertentu dengan alat inderanya secara teliti, menggunakan fakta yang relevan dan memadai dari hasil pengamatan, menggunakan alat atau bahan sebagai alat untuk mengamati objek dalam rangka pengumpulan data atau informasi. Mengamati dapat pula diartikan sebagai proses pengumpulan data tentang fenomena atau peristiwa dengan menggunakan inderanya. Keterampilan pengamatan dilakukan dengan cara menggunakan lima indera yaitu penglihatan, pembau, peraba, pengecap, dan pendengar. Pengamatan yang dilakukan hanya menggunakan indera disebut pengamatan kualitatif, sedangkan pengamatan yang dilakukan dengan menggunakan alat ukur disebut pengamatan kuantitatif. Pengamatan 


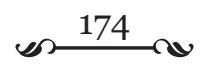

dapat dilakukan pada obyek yang sudah tersedia dan pengamatan pada suatu gejala atau perubahan. Contoh: sekelompok peserta didik diminta mengamati beberapa tepung yang berbeda jenisnya baik rasa, warna, ukuran serbuk dan baunya.

\begin{tabular}{|c|c|c|c|c|c|}
\hline Tepung & Warna & Rasa & Ukuran & Bentuk & Bau \\
\hline 1 & & & & & \\
\hline 2 & & & & & \\
\hline 3 & & & & & \\
\hline
\end{tabular}

\section{b. Klasifikasi}

Klasifikasi adalah proses yang digunakan ilmuwan untuk mengadakan penyusunan atau pengelompokan atas objek-objek atau kejadian. Keterampilan klasifikasi dapat dikuasai bila peserta didik telah dapat melakukan dua keterampilan berikut ini:

1) Mengidentifikasi dan memberi nama sifat-sifat yang dapat diamati dari sekelompok objek yang dapat digunakan sebagai dasar untuk mengklasifikasi

2) Menyusun klasifikasi dalam tingkat-tingkat tertentu sesuai dengan sifat-sifat objek

Keterampilan mengklasifikasikan atau menggolong-golongkan adalah salah satu kemampuan yang penting dalam kerja ilmiah. Klasifikasi berguna untuk melatih peserta didik menunjukkan persamaan, perbedaan, dan hubungan timbal baliknya. Guru hendaknya melatih peserta didik agar terampil dalam membuat klasifikasi, misalnya dengan mengelompokkan berbagai jenis daun-daunan menurut bentuk, warna, berduri tidaknya, berbulu tidaknya, dan corak tulang daun, mengelompokkan berbagai jenis burung menurut bentuk paruh, kaki, jenis makanan, dan cara hidupnya.

\section{c. Hubungan ruang/waktu}

Peserta didik dilatih agar terampil melihat hubungan ruang, mampu mengenal bentuk-bentuk, seperti lingkaran, persegi empat, persegi banyak, kubus, dan silinder. Peserta didik mampu mengenal arah, seperti bawah, atas, belakang, depan, kanan, kiri, utara, selatan, timur, barat, untuk menempatkan benda-benda sesuai rencana, untuk memasukkan 


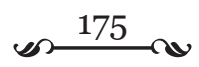

benda, menggabungkan, atau mencocokkan, untuk menggambarkan arah dan jarak. Peserta didik dilatih melihat hubungan waktu dengan belajar membuat urutan kejadian, membuat jam sederhana, menggunakan unit waktu, seperti menit, minggu, bulan, dan tahun, menyebutkan jam berapa sekarang, dan mengukur waktu suatu kejadian.

Ruang dan waktu berkaitan sangat erat, misalnya jika diperhatikan gerakan suatu benda. Benda bergerak dalam ruang, dan gerakannya berlangsung selama waktu tertentu. Guru dapat melatih peserta didik meneliti berapa waktu yang dibutuhkan untuk mengelilingi lapangan dengan berjalan kaki, berlari, dan naik sepeda. Peserta didik dapat mengukur kecepatan berjalan seekor siput per menit, seekor ulat, seekor semut, atau binatang lain.

\section{d. Menggunakan bilangan}

Keterampilan menggunakan bilangan atau angka adalah mengaplikasikan aturan-aturan atau rumus-rumus matematika dan fisika untuk menghitung jumlah atau menentukan hubungan dari pengukuran dasar. Kegiatan yang dapat digunakan untuk melatih keterampilan ini adalah latihan yang mengharuskan peserta didik untuk mengurutkan dan membandingkan benda-benda atau data berdasarkan faktor numerik. Contoh pertanyaan yang membantu peserta didik agar mengerti tentang hubungan bilangan antara lain adalah: "Lebih jauh mana benda A jika dibandingkan dengan benda B?" “ Berapa derajat suhu tersebut turun dari $-10^{\circ} \mathrm{C} \mathrm{ke}-20^{\circ} \mathrm{C}$ ?

\section{e. Melakukan pengukuran}

Keterampilan mengukur dapat dikembangkan melalui kegiatan yang berkaitan dengan pengembangan satuan-satuan yang cocok dari ukuran panjang, luas, isi, waktu, berat, dan sebagainya. Contoh: peserta didik melakukan pengukuran suhu menggunakan thermometer, menimbang berat benda dengan berbagai neraca, mengukur volume cairan menggunakan gelas ukur, mengukur panjang dengan menggunakan penggaris atau mengukur benda dengan jangka sorong. 


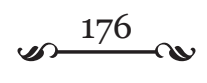

f. Menginferensi

Membuat kesimpulan sementara atau inferensi sering dilakukan oleh ilmuwan dalam proses penelitiannya. Guru melatih peserta didik dalam menyusun suatu kesimpulan sementara dalam proses penelitian sederhana yang dilakukan. Data dikumpulkan terlebih dahulu, kadang melalui percobaan terlebih dahulu, lalu dibuat kesimpulan sementara berdasarkan informasi yang dimiliki sampai suatu waktu tertentu. Kesimpulan tersebut bukan merupakan kesimpulan akhir, hanya merupakan kesimpulan sementara yang dapat diterima sampai pada saat itu. Contoh pembuatan kesimpulan sementara:

\begin{tabular}{|l|c|}
\hline \multicolumn{1}{|c|}{ Observasi } & Kesimpulan sementara \\
\hline Ia makan rumput & $\begin{array}{c}\text { Saya pikir binatang itu } \\
\text { adalah sapi }\end{array}$ \\
Kulitnya berwarna coklat & \\
\hline $\begin{array}{l}\text { Warna binatang itu indah } \\
\text { Binatang itu mempunyai tiga pasang } \\
\text { kaki }\end{array}$ & $\begin{array}{c}\text { Saya pikir binatang itu } \\
\text { adalah kupu-kupu }\end{array}$ \\
Namanya dimulai dengan huruf $\mathrm{K}$ & \\
\hline
\end{tabular}

g. Komunikasi

Komunikasi berarti menyampaikan pendapat hasil keterampilan proses lainnya baik secara lisan maupun tulisan. Tulisan bisa berbentuk hasil diskusi, rangkuman, grafik, tabel, gambar, poster, dan sebagainya. Keterampilan mengkomunikasikan ini diantaranya sebagai berikut:

a) Mengutarakan suatu gagasan

b. Menjelaskan penggunaan data hasil penginderaan/memeriksa secara akurat suatu objek atau kejadian

c. Mengubah data dalam bentuk tabel ke bentuk lainnya misalnya grafik, peta secara akurat.

h. Memprediksi

Memprediksi berarti mengemukakan apa yang mungkin terjadi pada keadaan yang belum diamati berdasarkan penggunaan pola yang 


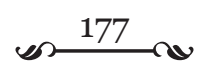

ditemukan sebagai hasil penemuan. Keterampilan meramalkan atau prediksi mencakup keterampilan mengajukan perkiraan sesuatu yang belum terjadi berdasarkan suatu kecenderungan atau pola yang sudah ada. Contoh: apa yang akan terjadi jika air dibiarkan di dalam piring lebar dibiarkan berhari-hari?

\section{i. Mengontrol Variabel}

Variabel adalah satuan besaran kualitatif atau kuantitatif yang dapat bervariasi atau berubah pada suatu situasi tertentu. Besaran kualitatif adalah besaran yang tidak dinyatakan dalam satuan pengukuran baku tertentu. Besaran kuantitatif adalah besaran yang dinyatakan dalam satuan pengukuran baku tertentu misalnya volume diukur dalam liter dan suhu diukur dalam ${ }^{\circ} \mathrm{C}$.

Keterampilan identifikasi variabel dapat diukur berdasarkan tiga tujuan pembelajaran berikut:

a) Mengidentifikasi variabel dari suatu pernyataan tertulis atau dari deskripsi suatu eksperimen.

b) Mengidentifikasi variabel manipulasi dan variabel respon dari deskripsi suatu eksperimen.

c) Mengidentifikasi variabel kontrol dari suatu pernyataan tertulis atau deskripsi suatu eksperimen.

Dalam suatu eksperimen terdapat tiga macam variabel yang sama pentingnya, yaitu variabel manipulasi, variabel respon dan variabel kontrol.

a) Variabel manipulasi adalah suatu variabel yang secara sengaja diubah atau dimanipulasi dalam suatu situasi.

b) Variabel respon adalah variabel yang berubah sebagai hasil akibat dari kegiatan manipulasi.

c) Variabel kontrol adalah variabel yang sengaja dipertahankan konstan agar tidak berpengaruh terhadap variabel respon.

j. Merumuskan Definisi Operasional

Mendefinisikan secara operasional suatu variabel berarti menetapkan bagaimana mengukur suatu variabel. Definisi ini harus 


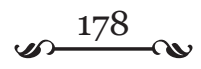

menyatakan tindakan apa yang akan dilakukan dan pengamatan apa yang akan dicatat dari suatu eksperimen. Contoh: peserta didik melakukan percobaan pengaruh suhu terhadap kelarutan gula dalam air. Rumusan hipotesisnya adalah semakin tinggi suhu air, makin cepat kelarutan gula. Data hasil observasi dapat dituliskan dalam tabel.

Data Hasil Observasi

\begin{tabular}{|c|c|c|}
\hline Volume air $\left(\mathrm{cm}^{3}\right)$ & Suhu air $\left({ }^{\circ} \mathrm{C}\right)$ & Waktu (detik) \\
\hline 100 & 25 & 30 \\
\hline 100 & 50 & 20 \\
\hline 100 & 80 & 10 \\
\hline
\end{tabular}

\section{Identifikasi variabel}

Variabel manipulasi : suhu

Variabel respon : : waktu

Variabel kontrol : volume air, thermometer, jenis air, gelas ukur, stopwatch, tempat air

\section{Definisi Operasional Variabel}

Manipulasi

Respon

Kontrol
: suhu air diukur menggunakan thermometer : waktu diukur dengan menggunakan stopwatch : alat-alat ukur seperti stopwatch, tempat air, thermometer, gelas ukur harus sama untuk semua percobaan

k. Menginterpretasi Data

Fakta atau data yang diperoleh dari hasil observasi sering kali memberikan suatu pola. Pola dari fakta/data ini dapat ditafsirkan lebih lanjut menjadi suatu penjelasan yang logis. Karakteristik keterampilan interpretasi diantaranya: mencatat setiap hasil pengamatan, menghubunghubungkan hasil pengamatan, menemukan pola atau keteraturan dari suatu seri pengamatan dan menarik kesimpulan.

Keterampilaninterpretasidatabiasanyadiawalidenganpengumpulan data, analisis data, dan mendeskripsikan data. Mendeskripsikan data artinya menyajikan data dalam bentuk yang mudah difahami misalnya bentuk tabel, grafik dengan angka-angka yang sudah dirata-ratakan. Data 


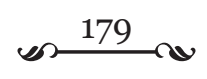

yang sudah dianalisis baru diinterpretasikan menjadi suatu kesimpulan atau dalam bentuk pernyataan. Data yang diinterpretasikan harus data yang membentuk pola atau beberapa kecenderungan.

\section{Merumuskan Hipotesis}

Hipotesis adalah dugaan tentang pengaruh apa yang akan diberikan oleh variabel manipulasi terhadap variabel respon. Hipotesis juga merupakan rumusan dugaan jawaban terhadap masalah. Hipotesis dirumuskan dalam bentuk pernyataan bukan pertanyaan. Hipotesis dinyatakan sebagai pengaruh yang diramalkan akan dimiliki suatu variabel terhadap variabel lain ( Nur \& Muslimin, 2007: 92).

Hipotesis dapat dirumuskan dengan penalaran induktif berdasarkan data hasil pengamatan atau dirumuskan dengan penalaran deduktif berdasarkan teori. Penalaran induktif adalah penalaran yang dilakukan berdasarkan data atau kasus menjadi pernyataan bersifat umum berupa simpulan yang dapat berbentuk hipotesis atau teori sementara. Penalaran deduktif adalah penalaran yang dilakukan berdasarkan teori menuju pernyataan simpulan yang bersifat khusus. Misalnya, peserta didik dalam satu kelas diukur tinggi badannya, kemudian ditimbang berat badannya, hasil pengukuran disajikan dalam bentuk tabel. Berdasarkan data pada tabel, dapat dirumuskan hipotesis secara induktif, yaitu semakin tinggi badan peserta didik, semakin berat tubuhnya.

m. Melakukan Eksperimen

Eksperimen merupakan kegiatan terinci yang direncanakan untuk menghasilkan data dalam menjawab suatu masalah atau menguji suatu hipotesis. Suatu eksperimen akan berhasil jika variabel yang dimanipulasi dan jenis respon yang diharapkan dinyatakan secara jelas dalam suatu hipotesis, juga penentuan kondisi-kondisi yang akan dikontrol sudah tepat. Melatihkan merencanakan eksperimen tidak harus selalu dalam bentuk penelitian yang rumit, tetapi cukup dilatihkan dengan menguji hipotesis-hipotesis yang berhubungan dengan konsep-konsep di dalam kurikulum. 


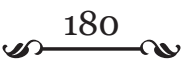

\section{Pentingnya Pendekatan Keterampilan Proses PadaPembelajaran IPA di Madrasah}

Peran keterampilan proses menurut Dahar (1985) dalam Devi (2010: 29) sebagai berikut:

a. Membantu peserta didik belajar mengembangkan pikirannya

b. Memberi kesempatan kepada peserta didik untuk melakukan penemuan

c. Meningkatkan daya ingat

d. Memberikan kepuasan intrinsik bila peserta didik telah berhasil melakukan sesuatu

e. Membantu peserta didik mempelajari konsep-konsep sains

Devi (2010: 29) menjelaskan bagaimana pendekatan keterampilan ini digunakan. Pendekatan keterampilan proses diaplikasikan pada pembelajaran dengan menggunakan prinsip-prinsip sebagai berikut:

a. Di dalam menyusun strategi mengajar, pengembangan keterampilan proses terintegrasi dengan pengembangan produk IPA

b. Keterampilan proses IPA, mulai dari mengamati hingga mengajukan pertanyaan tidak perlu merupakan suatu urutan yang harus diikuti dalam mengajarkan IPA

c. Setiap pendekatan atau metode mengajar yang diterapkan dalam pengajaran IPA dapat digunakan untuk mengembangkan keterampilan proses IPA. Jumlah dan macam keterampilan proses IPA tidak perlu sama untuk setiap metode, asal sesuai dengan tingkat perkembangan anak dan materi yang diajarkan

d. Pendekatan keterampilan proses tidak hanya dapat dikembangkan melalui kegiatan eksperimen atau praktikum, tetapi dapat pula dilatihkan melalui kegiatan non eksperimen atau diskusi.

Peran guru dalam mengembangkan keterampilan proses menurut Devi (2010: 30) adalah sebagai berikut:

a. Merencanakan dan melaksanakan kegiatan-kegiatan yang memberikan kesempatan kepada peserta didik untuk menggunakan keterampilan proses

b. Memberikan dorongan kepada peserta didik untuk menggunakan keterampilan proses

c. Memberikan bimbingan kepada peserta didik dalam mengembangkan 


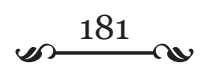

keterampilan proses

Guru membimbing dan mendidik peserta didik agar lebih terampil dalam menggunakan pengalaman, pendapat, dan hasil temuannya. Suasana belajar yang kondusif dapat mendorong peserta didik untuk berpartisipasi aktif, dengan merumuskan hasil pengamatan secara rinci, mengelompokkan atau mengklasifikasikan materi pelajaran yang diserap dari kegiatan pengamatan. Peserta didik dapat mengkomunikasikan hasil pengamatannya, dapat menyimpulkan suatu masalah, peristiwa berdasarkan fakta, konsep, dan prinsip yang diketahui.

Perencanaan guru dalam mengimplementasikan pendekatan keterampilan proses dituangkan dalam bentuk Rencana Pelaksanaan Pembelajaran (RPP) dan Lembar Kerja Peserta Didik (LKPD). Format RPP yang digunakan harus memenuhi tujuh komponen yaitu tujuan pembelajaran, materi pembelajaran, model/strategi/pendekatan/metode, langkah-langkah kegiatan (pendahuluan, inti, dan penutup), sumber/alat bantu dan penilaian.

Widyantini (2013: 4) menyatakan bahwa LKPD (student work sheet) adalah lembaran-lembaran berisi tugas yang harus dikerjakan oleh peserta didik. Struktur LKPD secara umum terdiri dari judul, mata pelajaran, semester, tempat, petunjuk belajar, kompetensi yang akan dicapai, indikator, informasi pendukung, langkah-langkah kerja serta penilaian. Manfaat LKPD ini dapat memudahkan guru dalam melaksanakan pembelajaran. Bagi peserta didik, akan melatih belajar mandiri dan belajar memahami suatu tugas secara tertulis.

Penilaian hasil belajar setelah menerapkan pendekatan keterampilan proses memiliki karakteristik dalam penyusunan butir soal disajikan pada tabel 3. Guru harus menguasai keterampilan proses dan menyajikan informasi yang perlu diolah. Informasi ini di buat pertanyaan atau pernyataan agar diperoleh respon atau jawaban yang diharapkan.

Tabel 3. Penilaian Keterampilan Proses

\begin{tabular}{|c|c|c|}
\hline No & $\begin{array}{c}\text { Aspek Keterampilan } \\
\text { Proses }\end{array}$ & \multicolumn{1}{|c|}{ Karakteristik Butir Soal } \\
\hline 1 & Observasi/pengamatan & $\begin{array}{l}\text { Terdapat obyek atau peristiwa yang } \\
\text { dapat diamati }\end{array}$ \\
\hline
\end{tabular}




\begin{tabular}{|c|c|c|}
\hline No & $\begin{array}{c}\text { Aspek Keterampilan } \\
\text { Proses }\end{array}$ & Karakteristik Butir Soal \\
\hline 2 & Klasifikasi & $\begin{array}{l}\text { Disajikan obyek/peristiwa yang dapat } \\
\text { ditemukan/dicari persamaan dan } \\
\text { perbedaan dari obyek tersebut atau } \\
\text { diberi kriteria tertentu untuk melakukan } \\
\text { pengelompokan }\end{array}$ \\
\hline 3 & Prediksi/meramalkan & $\begin{array}{l}\text { Pola atau kecenderungan yang jelas } \\
\text { untuk dapat diajukan suatu dugaan/ } \\
\text { ramalan }\end{array}$ \\
\hline 4 & Interpretasi & $\begin{array}{l}\text { Disajikan sejumlah data untuk } \\
\text { memperlihatkan pola }\end{array}$ \\
\hline 5 & Komunikasi & $\begin{array}{l}\text { Ada satu bentuk penyajian tertentu } \\
\text { untuk diubah ke bentuk penyajian } \\
\text { lainnya, misalnya bentuk uraian ke } \\
\text { bentuk bagan, bentuk tabel ke bentuk } \\
\text { grafik }\end{array}$ \\
\hline
\end{tabular}

Sumber: Devi (2010: 31)

Penilaian keterampilan proses IPA dapat berbentuk tes tertulis maupun observasi. Tes tertulis dapat dilakukan dengan menggunakan tes obyektif dan uraian. Untuk mengetahui bahwa proses kerja ilmiah itu benar-benar terjadi dan peserta didik memahami konsep dengan baik, maka dalam setiap pokok uji tes obyektif peserta didik dituntut untuk mengemukakan alasan mengapa ia memilih jawaban tersebut, sehingga dapat diinterpretasikan apakah peserta didik hanya menebak, salah konsep, tidak menguasai konsep dan keterampilan proses, atau menguasai konsep dan keterampilan proses. Penilaian dengan observasi dapat dilakukan pada setiap pembelajaran di kelas, di laboratorium maupun di lapangan dengan menggunakan format observasi penilaian keterampilan proses.

Berikut ini contoh penilaian keterampilan proses dalam bentuk tes obyektif atau pilihan ganda:

a. Reyhan menanam biji jagung pada tiga pot yang berukuran sama dengan jenis tanah pada setiap potnya berbeda (pot I tanah lempung, pot II tanah berpasir dan pot III tanah lumpur). Pot-pot diletakkan di dekat jendela yang terkena cahaya matahari dan disiram dengan sejumlah 


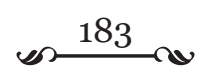

air yang sama. Pertumbuhan tanaman jagung diuji pada akhir hari ke 10 dan hasil menunjukkan pertumbuhan biji jagung pada ketiga pot berbeda. Menurut anda faktor apakah yang mempengaruhi perbedaan pertumbuhan biji jagung?

a) Jumlah cahaya matahari yang diterima tanaman jagung

b) Jenis tanah yang digunakan untuk menanam jagung

c) Suhu sekitar tanaman jagung

d) Jumlah klorofil yang dihasilkan tanaman jagung

b. Nadya mempunyai hobi menanam bunga mawar. Dia menanam 6 bunga mawar berwarna merah dan 6 bunga mawar berwarna putih. Seorang temannya mengatakan bahwa tanaman-tanaman mawar akan menghasilkan banyak bunga jika menerima sinar matahari pada pagi hari. Nadya memiliki pendapat berbeda, bahwa tanaman-tanaman mawarnya akan tetap menghasilkan jumlah bunga yang banyak, meskipun mendapat sinar matahari pada sore hari. Penjelasan manakah yang seharusnya dipilih untuk menguji ide-ide Nadya dan temannya tersebut?

a) Melakukan pengujian selama 4 bulan dengan mengatur semua tanaman bunga mawar agar mendapat sinar matahari pada pagi hari kemudian menghitung jumlah bunga yang dihasilkan setiap tanaman.

b) Melakukan pengujian selama 4 bulan dengan mengatur semua tanaman bunga mawar agar mendapat sinar matahari pada pagi hari, kemudian menghitung jumlah bunga yang dihasilkan selama kurun waktu 4 bulan tersebut. Selanjutnya selama 4 bulan juga mengatur semua tanaman mawar agar mendapat sinar matahari pada sore hari, kemudian menghitung jumlah bunga yang dihasilkan selama waktu 4 bulan.

c) Melakukan pengujian selama 4 bulan dengan mengatur 3 tanaman bunga mawar putih agar terkena sinar matahari pagi dan 3 tanaman bunga mawar putih agar terkena sinar matahari sore, kemudian menghitung jumlah bunga yang dihasilkan oleh setiap tanaman mawar putih.

d) Melakukan pengujian selama 4 bulan dengan cara mengatur 3 tanaman mawar putih dan tiga tanaman mawar merah agar terkena sinar matahari pagi, serta 3 tanaman bunga mawar putih dan 3 tanaman bunga mawar merah agar terkena sinar matahari sore, 


\section{enc 184}

kemudian menghitung jumlah bunga mawar yang dihasilkan setiap tanaman.

Peserta didik dapat mengerjakan soal dengan baik dan benar apabila telah melakukan percobaan tersebut, karena peserta didik dapat menemukan sendiri konsep yang dipelajari. Pendekatan keterampilan proses memiliki kelemahan antara lain memerlukan banyak waktu sehingga sulit untuk dapat menyesuaikan dengan materi pelajaran yang ditetapkan dalam kurikulum. Pendekatan keterampilan proses juga memerlukan fasilitas yang cukup baik dan lengkap, tentu saja tidak semua Madrasah dapat menyediakan peralatan praktikum yang lengkap. Merumuskan masalah, menyusun hipotesis, merancang suatu percobaan untuk memperoleh data yang relevan adalah kegiatan yang sulit, tidak setiap peserta didik mampu melaksanakan hal tersebut.

Peserta didik pada saat melakukan proses pembelajaran dinilai kinerjanya menggunakan lembar observasi. Contoh lembar observasi atau pengamatan kegiatan praktikum disajikan pada tabel 4. Pengamatan dilakukan mulai dari persiapan hingga kegiatan akhir praktikum.

Tabel 4. Lembar Pengamatan Kegiatan Praktikum

\begin{tabular}{|c|l|l|l|l|}
\hline \multirow{2}{*}{ No } & \multirow{2}{*}{ Aspek Kinerja yang Diharapkan } & \multicolumn{2}{|c|}{ Penilaian } & \multirow{2}{*}{ Keterangan } \\
\cline { 3 - 3 } A & PERSIAPAN & Ya & Tidak & \\
\hline & $\begin{array}{l}\text { 1. Menggunakan jas laboratorium } \\
\text { 2. Membawa alat dan bahan } \\
\text { praktikum }\end{array}$ & & & \\
\hline & $\begin{array}{l}\text { 3. Membersihkan alat-alat yang akan } \\
\text { digunakan }\end{array}$ & & \\
\hline & 4. Mengecek kesiapan alat dan bahan & & & \\
\hline B & 5. Membaca prosedur kerja & & & \\
\hline & 1. Menggunakan alat dan Bahan & & & \\
\hline & $\begin{array}{c}\text { M. Mengambil bahan tidak } \\
\text { berceceran }\end{array}$ & & & \\
\hline
\end{tabular}




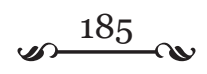

\begin{tabular}{|c|c|c|c|c|}
\hline \multirow{2}{*}{ No } & \multirow{2}{*}{ Aspek Kinerja yang Diharapkan } & \multicolumn{2}{|c|}{ Penilaian } & \multirow{2}{*}{ Keterangan } \\
\hline & & Ya & Tidak & \\
\hline & $\begin{array}{l}\text { b. Mengambil bahan sesuai } \\
\text { kebutuhan }\end{array}$ & & & \\
\hline & $\begin{array}{l}\text { c. Mengoperasikan alat dengan } \\
\text { benar }\end{array}$ & & & \\
\hline & $\begin{array}{l}\text { d. Menggunakan alat dan bahan } \\
\text { sesuai prosedur }\end{array}$ & & & \\
\hline & 2. Sikap & & & \\
\hline & a. Fokus pada kegiatan praktikum & & & \\
\hline & $\begin{array}{l}\text { b. Aktif dalam melakukan } \\
\text { praktikum }\end{array}$ & & & \\
\hline & c. Bekerjasama dalam kelompok & & & \\
\hline $\mathrm{C}$ & KEGIATAN AKHIR PRAKTIKUM & & & \\
\hline & a. Membersihkan alat dengan baik & & & \\
\hline & b. Membersihkan meja praktikum & & & \\
\hline & $\begin{array}{l}\text { c. Mengembalikan alat ke tempat } \\
\text { semula }\end{array}$ & & & \\
\hline
\end{tabular}

Sumber: Kemendikbud (2013: 290)

Pendekatan keterampilan proses akan efektif jika sesuai dengan kesiapan intelektual. Oleh karena itu, penerapan pendekatan keterampilan proses harus tersusun menurut aturan yang logis dan sesuai dengan tingkat kemampuan dan pengalaman peserta didik. Keterampilan proses dasar diterapkan untuk peserta didik di tingkat Madrasah Ibtidaiyah, sedangkan keterampilan proses terintegrasi diterapkan di tingkat Madrasah Tsanawiyah dan Aliyah.

\section{Simpulan}

Pendekatan keterampilan proses pada pembelajaran IPA merupakan pendekatan yang menekankan pada penumbuhan dan pengembangan sejumlah keterampilan proses sains pada diri peserta didik agar mampu memproses informasi sehingga ditemukan hal-hal yang baru yang bermanfaat baik berupa fakta, konsep, maupun pengembangan sikap dan nilai. Peserta 
didik berperan sebagai subyek dalam belajar. Peserta didik bukan hanya penerima informasi, tetapi sebaliknya sebagai pencari informasi, sehingga peserta didik harus aktif dan terampil untuk mampu mengelola pengalaman dan hasil belajarnya. Guru dalam pembelajaran IPA menggunakan pendekatan keterampilan proses sebaiknya membuat perencanaan yang baik dan membuat LKPD agar pembelajaran lebih terarah, efektif, dan berpengaruh positif terhadap hasil belajar peserta didik. 


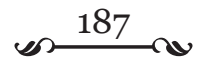 \\ DAFTAR PUSTAKA}

Chiappetta, E.L. \& Koballa, T.R. 2010. Science Instruction in the Middle and Secondary Schools Developing Fundamental Knowledge and Skills ( $7^{\text {th }}$ ed). Boston: Allyn \& Bacon.

Devi, Poppy Kamalia. 2010. Keterampilan Proses dalam Pembelajaran IPA untuk Guru SMP. Pusat Pengembangan dan Pemberdayaan Pendidik dan Tenaga Kependidikan Ilmu Pengetahuan Alam (PPPPTK IPA).

Hosnan. 2014. Pendekatan Saintifik dan Kontekstual dalam Pembelajaran Abad 21 Kunci Sukses Implementasi Kurikulum 2013. Bogor: Penerbit Ghalia Indonesia.

Kemendikbud. 2013. Materi Pelatihan Guru Implementasi Kurikulum 2013 SMP/MTs IPA. Badan Pengembangan Sumber Daya Manusia Pendidikan dan Kebudayaan dan Penjaminan Mutu Pendidikan, Jakarta.

Khaeruddin, Junaedi, M., Mansur, Sudibyo, Suhito, Basuki, Ismail, Nurasik \& Rahman, M. 2007. Kurikulum Tingkat Satuan Pendidikan Konsep dan Implementasinya di Madrasah. Jogjakarta: Pilar Media.

Mulyasa. 2014. Pengembangan dan Implementasi Kurikulum 2013. Bandung: PT Remaja Rosdakarya.

Nur, Muhamad \& Muslimin. 2007. Hakikat Sains. Yogyakarta: Program Studi Pendidikan Dasar Program Pascasarjana Universitas Negeri Yogyakarta.

Rustaman, N.Y. 2003. Strategi Belajar Mengajar Biologi. Bandung: Jurusan Pendidikan Biologi FMIPA UPI.

Semiawan, Conny., Tangyong, A.F., Belen, S., Matahelemual, Y \& Suseloardjo, Wahjudi. 1989. Pendekatan Ketrampilan Proses Bagaimana Mengaktifkan Peserta didik dalam Belajar?. Jakarta: PT Gramedia.

Widyantini, Theresia. 2013. Penyusunan Lembar Kerja Peserta didik (LKS) sebagai Bahan Ajar. Artikel. Pusat Pengembangan dan Pemberdayaan Pendidik dan Tenaga Kependidikan (PPPPTK) Matematika. 